Kredo 4 (2021)
KREDO: Jurnal Ilmiah Bahasa dan Sastra
Terakreditasi Sinta 4 berdasarkan Keputusan Direktorat
Jenderal Penguatan Riset dan Pengembangan,
Kementerian Riset, Teknologi dan Pendidikan Tinggi
Republik Indonesia
Nomor: 23/E/KPT/2019. 08 Agustus 2019
https://jurnal.umk.ac.id/index.php/kredo/index

\title{
KECERDASAN EMOSIONAL DALAM KARYA FIKSI ASMA NADIA
}

\author{
Suprihatma \\ hatmaprabu@gmail.com \\ Universitas Selamat Sri, Indonesia
}

\author{
Info Artikel \\ Sejarah Artikel \\ Diterima \\ 12 September 2020 \\ Disetujui \\ 14 April 2021 \\ Dipublikasikan \\ 30 April 2021
}

\section{Keywords}

Emotional Intelligence;

Fiction Works; Asma

Nadia

\section{Kata Kunci}

Kecerdasan Emosional; Karya Fiksi; Asma Nadia
This paper aims to examine the form of intelligence as the main intelligence in Asma Nadia's novel Notes of a Wife's Heart. This research is included in the category of literary research, with literary psychology approach and qualitative research. The theory used to study the novel Notes Hati a Wife is the theory of structuralism, the nature of the novel, literary psychology, and emotional intelligence. The data was collected using literature techniques through content review techniques. The data analysis technique used in this study was an interactive analysis technique developed by Miles and Huberman. The results showed that the expression of the main character's intelligence in the novel Sorang Wife's Heart Note is a personal intelligence. Intelligence is divided into five parts, namely: emotional awareness, emotions, self-motivation, other people's emotions and relationships. The character of the main character's emotional intelligence work in the novel, Notes Hati Sorang : Wife Asma Nadia, the starting point rests on the main point.

\section{Abstrak}

Tulisan ini bertujuan untuk mengkaji wujud ekspresi kecerdasan emosional tokoh utama novel : Catatan Hati Seorang Istri karya Asma Nadia. Penelitian ini termasuk dalam kategori penelitian sastra, dengan pendekatan psikologi sastra dan termasuk jenis penelitian kualitatif. Teori yang digunakan untuk meneliti novel Catatan Hati Seorang Istri adalah teori strukturalisme, hakikat novel, psikologi sastra, dan kecerdasan emosional. Pengumpulan data dilakukan dengan teknik kepustakaan melalui teknik kajian isi. Teknik analisis data yang digunakan dalam penelitian ini adalah teknik analisis interaktif yang dikembangkan oleh Miles dan Huberman. Hasil penelitian menunjukkan bahwa wujud ekspresi kecerdasan emosional tokoh utama dalam novel Catatan hati Sorang Istri merupakan kecerdasan pribadi. Kecerdasan tersebut dibagi menjadi lima bagian antara lain: mengenali emosi diri, mengelola emosi, memotivasi diri sendiri, mengenali emosi orang lain dan membina hubungan. Wujud ekspresi kecerdasan emosional tokoh utama pada novel Catatan hati Sorang Istri karya Asma Nadia titik tolaknya bertumpu pada tokoh utama pada masing-masing cerita tersebut.

\section{$611 \mid$ Jurnal Kredo}

Vol. 4 No. 22021 


\begin{tabular}{|c|c|c|} 
Kredo 4 (2021) \\
KREDO: Jurnal Ilmiah Bahasa dan Sastra \\
Terakreditasi Sinta 4 berdasarkan Keputusan Direktorat \\
Jenderal Penguatan Riset dan Pengembangan, \\
Kementerian Riset, Teknologi dan Pendidikan Tinggi \\
Republik Indonesia \\
Nomor: 23/E/KPT/2019. 08 Agustus 2019 \\
https://jurnal.umk.ac.id/index.php/kredo/index
\end{tabular}

\section{PENDAHULUAN}

Karya fiksi pada dasarnya adalah cermin dari hidup manusia. Pengarang melalui karya fiksinya dapat menyampaikan berbagai gagasan maupun ide yang timbul dari permasalahan yang ada pada manusia dan lingkungannya. Hal itu sejalan dengan pendapat Suharianto (2005:15). Lebih lanjut Suharianto (2005:19) mengatakan melalui karya sastra seorang pengarang bermaksud menyampaikan gagasan-gagasan, pandangan hidup, tanggapan atas kehidupan sekitarnya dan sebagainya dengan cara yang diusahakan menarik pembaca untuk menyampaikan nilai-nilai yang menurut keyakinan dapat bermanfaat. Maka pengarang berusaha menjadikan karya sastra sedemikian rupa agar menarik perhatian pembaca.

Dalam karya sastra, pengarang dalam mengekspresikan pengalamannya, telah mengalami proses pengolahan jiwa secara mendalam. Dari berbagai jenis karya sastra salah satu jenisnya yaitu novel. Novel sebagai sebuah karya fiksi menawarkan sebuah dunia. Dunia yang berisi model kehidupan yang diidealkan sehingga muncullah yang diinginkan pengarang oleh karena itu cerita fiksi sering dianggap dapat membuat manusia lebih arif, bijaksana dan berbudaya atau dapat dikatakan sebagai karya yang dapat "memanusiakan manusia" (Nurgiyantoro 2012:4).
Kecerdasan emosional (EI) oleh Badner (melalui Goleman 2005:57) disebut sebagai kecerdasan pribadi yang dari perasaan itu merupakan sejenis kepekaan yang memungkinkan manusia secara efektif menangkap pesan. Pesan yang tidak terucap. Dalam diri manusia satu dengan yang lainnya memiliki campuran kecerdasan emosional dengan kadar yang berbeda-beda. Namun kecerdasan emosional banyak menumbuhkan sifat-sifat dalam diri manusia.

Ahli psikologi ini Stenberg dan Salovely termasuk di antaranya telah menganut pandangan pandangan kecerdasan yang lebih luas, berusaha menemukan kembali dalam kerangka apa yang dibutuhkan untuk meraih sukses dalam kehidupannya. Dan jalur penelitian tersebut menuntun kembali pada pemahaman betapa pentingnya kecerdasan "pribadi" atau kecerdasan emosional (Goleman 1997:57). Sehingga kecerdasan emosional sangat penting untuk dipahami, karena dapat mengungkap persolan psikologi atau kejiwaan tokoh dalam karya sastra yang timbul akibat tidak ada pengertian satu sama lain.

Penelitian tentang psikologis memang sudah banyak, tetapi penelitian yang akan dilakukan di sini lebih menekankan pada kecerdasan emosional tokoh yang diambil dari novel Catatan Hati Seorang Istri. Novel Catatan Hati Seorang Istri ini menceritakan tentang 


\begin{tabular}{|c|c|c|} 
Kredo 4 (2021) \\
KREDO: Jurnal Ilmiah Bahasa dan Sastra \\
Terakreditasi Sinta 4 berdasarkan Keputusan Direktorat \\
Jenderal Penguatan Riset dan Pengembangan, \\
Kementerian Riset, Teknologi dan Pendidikan Tinggi \\
Republik Indonesia \\
Nomor: 23/E/KPT/2019. 08 Agustus 2019 \\
https://jurnal.umk.ac.id/index.php/kredo/index
\end{tabular}

kisah keseharian seorang perempuan dengan segala permasalahan prahara rumahtangganya menjadi perhatian yang serius banyak diungkap dalam karya sastra, salah satunya adalah novel "Catatan Hati Seorang Istri" karya Asma Nadia. Tokoh Asma yang mempunyai berbagai persolan dalam hidupnya tentang bagaimana cara mengendalikan diri atau mengelola emosi diri sendiri saat menghadapi persoalan kehidupan rumahtangga, serta harus mampu memotivasi diri sendiri dan mampu membina hubungan dengan orang lain khususnya dalam keluarga dan tokoh-tokoh lain dalam novel Catatan Hati Seorang Istri yang mempunyai berbagai permasalahan. Cinta, pengkhianatan, kesetiaan, pengorbanan dan keteguhan hati. Inilah makna yang terangkum dalam novel karya salah satu penulis wanita kaliber tanah air ini. Novel ini berisi berbagai macam kisah menyentuh hati dan menggetarkan tentang perjuangan perempuan, seorang istri, sekaligus ibu dalam menghadapi berbagai prahara rumah tangga. Dan kita menjadi saksi, betapa kesulitan dan ketabahan mesti selalu beriringan dalam perjuangan, serta betapa berlikunya jalan menuju keikhlasan.

Berdasarkan hal itulah penelitian ini perlu dikaji kecerdasan emosional lebih lanjut. Gambaran tokoh yang banyak mengalami berbagai permasalahan yang menarik untuk 613 | Jurnal Kredo

Vol. 4 No. 22021 diteliti melalui pendekatan kecerdasan emosional. Wujud ekspresi kecerdasan emosional tokoh akan terlihat.

Asma Nadia (lahir di Jakarta, 26 Maret 1972; umur 43 tahun) adalah seorangpenulis novel dan cerpen Indone sia. Ia dikenal sebagai pendiri Forum Lingkar Pena dan manajer Asma Nadia Publishing House. Setelah lulus dari SMA 1 Budi Utomo, Jakarta, ia melanjutkan kuliah di Fakultas Teknologi Pertanian di Institut Pertanian Bogor. Ia tidak menyelesaikan kuliah yang dijalaninya, karena ia harus beristirahat karena penyakit yang dideritanya. Ia mempunyai obsesi untuk terus menulis. Ketika kesehatannya menurun, ia tetap bersemangat menulis.

Karena karya-karyanya, ia pernah mendapat berbagai penghargaan. Selain menulis, Asma sering diminta untuk memberikan materi dalam berbagai lokakarya yang berkaitan dengan penulisan dan feminisme, baik di dalam dan di luar negeri. Pada tahun 2009 dalam perjalanannya keliling Eropa setelah mendapatkan undangan writers in residence dari Le Chateau de Lavigny (AgustusSeptember 2009), ia sempat diundang untuuk memberikan seminar dan wawancara kepenulisan di PTRI Jenewa, Masjid Al Falah Berlin (bekerja sama dengan FLP dan KBRI di sana), KBRI Roma, Manchester (dalam acara KIBAR Gathering), dan Newcastle. 


Kredo 4 (2021)
KREDO: Jurnal Ilmiah Bahasa dan Sastra
Terakreditasi Sinta 4 berdasarkan Keputusan Direktorat
Jenderal Penguatan Riset dan Pengembangan,
Kementerian Riset, Teknologi dan Pendidikan Tinggi
Republik Indonesia
Nomor: 23/E/KPT/2019. 08 Agustus 2019
https://jurnal.umk.ac.id/index.php/kredo/index

Sejak awal tahun 2009, ia merintis penerbitan sendiri dengan nama Asma Nadia Publishing House. Beberapa bukunya yang telah diadaptasi menjadi film adalah Emak Ingin Naik Haji, Rumah Tanpa Jendela, Assalamualaikum Beijing dan Catatan Hati Seorang Istri. Berdasarkan latar belakang tersebut peneliti tertarik untuk meneliti kecerdasan emosional tokoh dalam novel "Catatan Hati Seorang Istri” karya Asma Nadia.

Penelitian psikologi sastra sudah dilakukan oleh beberapa peneliti sebelumnya. Penelitian-penelitian terdahulu yang pernah dilakukan tersebut memiliki kaitan dengan penelitian yang dilakukan saat ini. Penelitian terdahulu yang relevan, bertujuan untuk memberikan gambaran hasil penelitian yang dapat dijadikan acuan dalam mengembangkan penelitian yang baru terkait dengan tema dan atau pokok bahasan yang sama. Adapun beberapa penelitian terdahulu yang mirip dengan penilitian ini. Diantaranya: Yuliana (2004), Nugraheni (2006), Hartono (2006), Kartika (2008), Simma (2009), Suhanto (2009), Litrev (2010), Pulido (2011), Griswold (2003), Gartner et al (1991), Frank (1996), Thomas (2006), dan Taylor (2002).

Yuliana (2004) meneliti konflik batin tokoh utama cerpen Ca-Bau-Kan karya Remi Sylado: sebuah pendekatan psikologi sastra. Hasil dari penelitian ini adalah konflik yang dialami tokoh utama dalam cerpen ini mempengaruhi sikap dan tingkah laku untuk memenuhi kebutuhan, adanya perbedaan atau salah paham dan adanya sasaran yang samasama dikejar oleh kedua belah pihak sehingga mempengaruhi 8 sikap dan tingkah laku masyarakat dalam bentuk tindakan menyimpang dari norma-norma dalam masyarakat. Penelitian Yuliani tersebut sama-sama tentang psikologi tokoh utama.

Adapun perbedaannya penelitian tersebut hanya difokuskan pada cerpen Ca-Bau-Kan karya Remi Sylado. Penelitian tersebut belum mengarah pada aspek kepribadian tokoh dalam novel. Untuk itu penelitian ini dilakukan untuk upaya melengkapi kajian struktur novel yang difokuskan pada analisis tokoh utama pada novel yang berbeda yaitu novel Catatan Hati Seorang Istri karya Asma Nadia sehingga sangat relevan dengan penelitian sebelumnya.

Nugraheni (2006) meneliti konflik batin tokoh Zaza dalam cerpen Azalea Jingga karya Naning Pranoto: tinjauan psikologi sastra. Hasil penelitian ini yaitu konflik yang dialami tokoh utama bernama Zaza. Tokoh Zaza harus dihadapkan pada dua pilihan yang berat antara kesetiaan serta kecintaan seorang istri terhadap suaminya, dan kenyataan pahit yang harus dihadapi bahwa suaminya telah beristri tanpa sepengetahuan Zaza sebelumnya sehingga membuat adanya beberapa konflik batin dalam dirinya. 


Kredo 4 (2021)
KREDO: Jurnal Ilmiah Bahasa dan Sastra
Terakreditasi Sinta 4 berdasarkan Keputusan Direktorat
Jenderal Penguatan Riset dan Pengembangan,
Kementerian Riset, Teknologi dan Pendidikan Tinggi
Republik Indonesia
Nomor: 23/E/KPT/2019. 08 Agustus 2019
https://jurnal.umk.ac.id/index.php/kredo/index

Ada kesamaan dengan penelitian ini yaitu sama-sama tentang psikologi sastra tokoh utama. Sementara itu objek penelitian tersebut tentang cerpen Azalea Jingga karya Naning Pranoto. Untuk itu penelitian ini dilakukan untuk upaya melengkapi kajian dengan objek yang berbeda yaitu novel Catatan Hati Seorang Istri karya Asma Nadia. Kajian psikologi sastra sangat relevan dilakukan karena penelitian ini masih terkait erat dengan penelitian sebelumnya, hanya saja objek kajiannya yang berbeda.

Hartono (2006) melakukan penelitian yang berjudul "Kepatuhan dan Kemandirian Santri Sebuah Analisis Psikologis". Dalam penelitian tersebut dikupas kepatuhan santri sebagian besar pada tingkat yang tinggi dan sedang. Hal tersebut mencerminkan santri masih memiliki kecenderungan untuk percaya pada kiai, dapat menerima sikap dan tingkah-lakunya, serta melaksanakan perintah atau permintaan kiai, sehingga santri tersebut memiliki kecenderungan untuk mengubah sikap dan tingkah laku untuk mengikuti perintah atau permintaan kiai sebagai bentuk rasa hormat santri.

Adapun persamaan dengan penelitian ini yaitu sama-sama tentang psikologi sastra. Letak perbedaannya penelitian tersebut tentang kepatuhan dan kemandirian santri. Sementara peneliti mengkaji novel Catatan Hati Seorang Istri karya Asma Nadia sehingga sangat relevan dengan 615 | Jurnal Kredo

Vol. 4 No. 22021 penelitian sebelumnya. Relevansinya penelitian ini masih terkait erat dengan penelitian sebelumnya, hanya saja objek kajiannya yang berbeda.

Kartika (2008) melakukan penelitian berjudul "Konflik Batin Tokoh Utama dalam novel Nayla karya Djenar Maesa Ayu: Tinjauan Psikologi Sastra". Hasil dari penelitian ini adalah (1) Nayla mengalami konflik batin akibat tidak terpenuhinya kebutuhan kasih sayang dari seorang ayah; (2) Nayla mengalami konflik batin karena tidak terpenuhinya kebutuhan akan rasa aman yakni selalu merasakan ketakutan dan seolah-olah berada dalam keadaan terancam; (3) konflik batin akibat profesinya di diskotik yang banyak mengundang cibiran orang. Penelitian Kartika mempunyai persamaan dengan penelitian ini yaitu sama-sama tentang psikologi sastra.

Perbedaan penelitian itu dengan penelitian ini terletak pada objek sasaran yang diteliti. Pada penelitian tersebut difokuskan pada konflik batin tokoh utama novel Nayla. Sementara pada penelitian ini objek yang dikaji yaitu novel Catatan Hati Seorang Istri karya Asma Nadia. Keterkaitan hal tersebut dengan penelitian sebelumnya dapat dijadikan gambaran peneliti dengan objek yang berbeda.

Simma (2009) dalam tesisnya yang berjudul "An Analysis of Defense Mechanisms Used by The Main Characters in Mark Twain's The 


\begin{tabular}{|c|c|c|} 
Kredo 4 (2021) \\
KREDO: Jurnal Ilmiah Bahasa dan Sastra \\
Terakreditasi Sinta 4 berdasarkan Keputusan Direktorat \\
Jenderal Penguatan Riset dan Pengembangan, \\
Kementerian Riset, Teknologi dan Pendidikan Tinggi \\
Republik Indonesia \\
Nomor: 23/E/KPT/2019. 08 Agustus 2019 \\
https://jurnal.umk.ac.id/index.php/kredo/index
\end{tabular}

Adventures of Huckleberry Finn and The Prince and The Pauper". Dalam kajian ini, Simma menggunakan teori mekanisme pertahanan ego dari teori Sigmund Freud. Simma menyimpulkan bahwa kedua tokoh utama dalam novel tersebut yaitu Huck dan Edward memakai metode pertahanan yang sama yaitu regression, suppression, dan rationalization ketika mereka memiliki masalah kecemasan. Penyebab kecemasan mereka hampir sama yaitu latar belakang keluarga dan kondisi sosial masyarakat. Permasalahan yang mereka alami membuat mereka hanya dapat melakukan regression, supression karena mereka tidak bisa balik melawan orang- orang dewasa di sekitar mereka. Selain itu mereka juga memakai rationalization untuk tujuan yang sama. Hal tersebut sesuai dengan penelitian yang dilakukan saat ini.

Sejalan dengan penelitian Simma ini yaitu sama-sama tentang psikologi sastra. Di satu sisi penelitian tersebut mengkaji perbandingan tokoh utama. Di sisi yang berbeda penelitian ini dilakukan untuk upaya melengkapi penelitian sebelumnya dengan kajian dan objek yang berbeda yaitu novel Catatan Hati Seorang Istri karya Asma Nadia. Adanya keterkaitan hal tersebut sangat relevan dengan penelitian sebelumnya.

Thomas (2006) dalam artikel jurnalnya yang berjudul "A Metaanalytic Test of Intergroup Contact
Theory". Dalam penelitian ini, Thomas mencoba untuk menentukan bagaimana mencegah kontak antar kelompok dari prasangka serta pengembangan teori yang lebih komprehensif dari kontak antar kelompok.

Penelitian Thomas tersebut mempunyai persamaan dengan penelitian ini yaitu sama-sama tentang psikologi sastra. Adapun yang membedakan penelitian terdahulu mengkaji bagaimana mencegah kontak antar kelompok dari prasangka serta pengembangan teori yang lebih komprehensif dari kontak antar kelompok. Sementara itu pada penelitian ini objek kajiannya yaitu novel Catatan Hati Seorang Istri karya Asma Nadia. Dalam aspek kajiannya juga berbeda dengan penelitian sebelumnya. Relevansinya penelitian ini masih terkait ranah pendekatan yang digunakan dengan penelitian sebelumnya yaitu pendekatan psikologi.

Taylor (2002) dalam "Body and Technology: Refreming the Humanistic Critique (Kritik tokoh psikologi humanistik terhadap teknologi)". Dalam penelitian ini, disimpulkan terdapat kritik tokoh psikologi humanistik perihal teknologi. Penelitian Taylor mempunyai persamaan dengan penelitian ini yaitu sama-sama tentang psikologi sastra. Sementara itu letak perbedaannya pada aspek kajian yang digunakan. Adapun aspek kajian dalam penelitian ini yaitu aspek kecerdasan emosional tokoh 


\begin{tabular}{|c|c|c|} 
Kredo 4 (2021) \\
KREDO: Jurnal Ilmiah Bahasa dan Sastra \\
Terakreditasi Sinta 4 berdasarkan Keputusan Direktorat \\
Jenderal Penguatan Riset dan Pengembangan, \\
Kementerian Riset, Teknologi dan Pendidikan Tinggi \\
Republik Indonesia \\
Nomor: 23/E/KPT/2019. 08 Agustus 2019 \\
https://jurnal.umk.ac.id/index.php/kredo/index
\end{tabular}

utama novel Catatan Hati Seorang Istri karya Asma Nadia sehingga sangat relevan dengan penelitian sebelumnya. Berdasarkan uraian tentang hasil penelitian terdahulu, maka dapat dilihat bahwa orisinilitas penelitian dengan judul kecerdasan emosional tokoh dalam novel Catatan Hati Seorang Istri karya Asma Nadia dapat dipertanggungjawabkan.

Berdasarkan informasi dari seluruh penelitian tersebut, dapat disimpulkan bahwa penelitian tentang kecerdasan emosional tokoh utama novel Catatan Hati Seorang Istri karya Asma Nadia ini belum pernah dilakukan oleh peneliti terdahulu. Akan tetapi, penelitian tentang analisis tokoh utama dengan pendekatan psikologi sastra, sudah banyak dilakukan oleh peneliti terdahulu. Dengan demikian, penelitian tersebut dapat dilengkapi dengan penelitian ini dengan memaparkan bagaimana wujud ekspresi kecerdasan emosional tokoh utama novel Catatan Hati Seorang Istri karya Asma Nadia.

Bertolak dari permasalahan tersebut, tujuan yang hendak dicapai dalam penelitian ini adalah:

(1) Menemukan tokoh utama dalam novel Catatan Hati Seorang Istri Karya Asma Nadia;

(2) Menemukan gambaran emosi tokoh utama novel Catatan Hati Seorang Istri karya Asma Nadia; dan

617 | Jurnal Kredo

Vol. 4 No. 22021
(3) Memaparkan wujud ekspresi kecerdasan emosional tokoh utama novel Catatan Hati Seorang Istri karya Asma Nadia.

\section{KAJIAN TEORI}

Teori yang digunakan untuk meneliti novel Catatan Hati Seorang Istri adalah 1) teori strukturalisme, 2) hakikat novel, 3) psikologi sastra, dan 4) kecerdasan emosional.

\section{Teori Strukturalime}

Dalam buku berjudul Sastra dan Ilmu Sastra, A Teeuw (1988:120-140) dideskripsi kemunculan aliran Strukturalis atau Strukturalisme pendekatan ilmu-ilmu manusia yang berupaya menganalisis bidang tertentu (misalnya, mitologi) sebagai system kompleks yang saling berhubungan. Sebuah karya sastra akan bermakna jika ada kaitan dalam keseluruhan. Lebih jauh Teeuw (1988:61) memaparkan bahwa menganalisis struktur karya sastra yang ingin diteliti dari segi manapun juga merupakan tugas prioritas, pekerjaan pendahuluan, sebab karya sastra sebagai dunia dalam kata yang mempunyai kebulatan makna intrinsik yang hanya dapat digali dari karya itu sendiri. Selanjutnya, Teeuw (1988:135) juga mengemukakan tujuan analisis struktural ialah untuk membongkar, dan memaparkan secermat mungkin keterjalinan dan keterjalinan semua 


Kredo 4 (2021)
KREDO: Jurnal Ilmiah Bahasa dan Sastra
Terakreditasi Sinta 4 berdasarkan Keputusan Direktorat
Jenderal Penguatan Riset dan Pengembangan,
Kementerian Riset, Teknologi dan Pendidikan Tinggi
Republik Indonesia
Nomor: 23/E/KPT/2019. 08 Agustus 2019
https://jurnal.umk.ac.id/index.php/kredo/index

analisis dan aspek karya sastra dan bersama-sama menghasilkan makna menyeluruh. Dengan kata lain, struktur merupakan totalitas dari kesatuan unsurunsurnya. Unsur-unsur itu saling berhubungan dan saling menentukan.

\section{Hakikat Novel}

Menurut Semi menyatakan bahwa novel merupakan karya sastra yang mengungkapkan suatu konsentrasi kehidupan pada suatu saat tegang, dan pemusatan kehidupan yang tegas. Pengarang bermaksud mengubah jalan nasib tokoh misalnya tegas, benci, cinta, curiga dan tidak percaya. Jadi novel adalah salah satu bentuk karya sastra yang melukiskan kehidupan dalam bentuk cerita yang menampilkan tokohtokoh serta latar yang dijalin dalam rangkaian peristiwa. Berdasarkan uraian tersebut dapat ditarik simpulan bahwa novel adalah karya sastra berbentuk prosa yang di dalamnya terdapat tokohtokoh dengan menampilkan serangkaian peristiwa dan tersusun membentuk satu kesatuan makna dalam sebuah cerita.

\section{Unsur Pembangun Novel}

Novel mempunyai unsur pembangun yang secara garis besar terbagi menjadi dua bagian, yaitu 1) unsur ekstrinsik dan 2) unsur intrinsik. Unsur ekstrinsik adalah segala unsur yang berbeda di luar suatu novel yang ikut mempengaruhi kehadiran karya sastra tersebut, misalnya faktor sosial, ekonomi, faktor kebudayaan, faktor sosial-politik, keagamaan dan tata nilai yang dianut masyarakat. Unsur intrinsik adalah unsur-unsur yang membentuk karya sastra tersebut, seperti penokohan atau perwatakan, tema, alur (plot), pusat pengisahan latar dan gaya bahasa (Semi 1993:35).

\section{Unsur Intrinsik}

Unsur Intrinsik merupakan unsur pembangun karya sastra yang berasal dari dalam karya itu sendiri (Nurgiyantoro 2009:23). Berikut ulasan unsur-unsur intrinsik novel.

\section{Tokoh}

Menurut Nurgiyantoro (2012:165) menjelaskan "istilah 'tokoh' menunjuk pada orangnya, pelaku cerita". Sementara itu menurut Aminuddin (2013:79), para tokoh yang terdapat dalam cerita memiliki peranan yang berbeda-beda. Seorang tokoh yang memiliki peranan penting dalam suatu cerita disebut dengan tokoh inti atau tokoh utama. Sementara itu tokoh yang memiliki peranan tidak penting karena pemunculannya hanya melengkapi, melayani, mendukung pelaku utama disebut tokoh tambahan atau tokoh pembantu.

Senada dengan yang telah diungkapkan Aminuddin (2000:74) mengemukakan bahwa ditinjau dari keterlibatan dalam keseluruhan cerita, tokoh fiksi dibedakan menjadi dua, yakni tokoh sentral atau tokoh utama dan tokoh periferalatau tokoh tambahan (bawahan). Tokoh utama adalah tokoh yang menjadi peran mutlak dalam cerita, 


\begin{tabular}{|c|c|c|} 
Kredo 4 (2021) \\
KREDO: Jurnal Ilmiah Bahasa dan Sastra \\
Terakreditasi Sinta 4 berdasarkan Keputusan Direktorat \\
Jenderal Penguatan Riset dan Pengembangan, \\
Kementerian Riset, Teknologi dan Pendidikan Tinggi \\
Republik Indonesia \\
Nomor: 23/E/KPT/2019. 08 Agustus 2019 \\
https://jurnal.umk.ac.id/index.php/kredo/index
\end{tabular}

tokoh yang paling sering muncul, dan yang menjadi pusat perhatian pembaca. Tokoh sentral dibedakan menjadi dua, yaitu: (1) tokoh sentral protagonis dan (2) tokoh sentral antagonis.

Lebih lanjut Aminuddin (2000:76) mengungkapkan bahwa berdasarkan watak dan karakternya, yakni segi-segi yang mengacu pada perbauran antara minat, keinginan, emosi dan moral yang membentuk individu tokoh, dikenal adanya tokoh sederhana, simple, atau flatc characters dan tokoh kompleks, complex, atau round caracters.

Dilihat dari segi peranan dan tingkat pentingnya tokoh dibedakan menjadi dua, yaitu tokoh utama sentral dan tokoh bawahan.

\section{a. Tokoh utama atau sentral}

Menurut Aminudin (1995:80), tokoh utama dapat ditentukan melalui judul cerita. Jadi tokoh yang namanya diangkat sebagai judul cerita dapat mengungkapkan tokoh utama. Dengan begitu dapat disimpulkan bahwa tokoh utama ialah tokoh yang pemunculannya diutamakan dan memiliki peranan terpenting dalam sebagian besar peristiwa dalam cerita. Tokoh yang memegang peranan pimpinan disebut tokoh utama. Adapun tokoh sentral dibedakan antara lain tokoh protagonis, antagonis, wirawan, dan antiwirawan.

\section{b. Tokoh bawahan}

Tokoh bawahan adalah tokoh yang tidak sentral. Kedudukannya di 619 | Jurnal Kredo

Vol. 4 No. 22021 dalam cerita, tetapi kehadirannya sangat diperlukan untuk menunjang atau mendukung tokoh utama. Ada tokoh bawahan yang sulit disebut tokoh karena tidak memegang peranan di dalam cerita. Tokoh bawahan adalah tokoh yang kehadirannya lebih sedikit dibanding tokoh utama. Kehadirannya hanya ada jika bertapa atau berhubungan dengan tokoh utama secara langsung (Nurgiyantoro 2000:177).

\section{Penokohan atau Perwatakan}

Suharianto

(1982:31)

memberikan definisi penokohan atau perwatakan sebagai berikut, "penokohan atau perwatakan ilalah pelukisan mengenai tokoh cerita baik dengan keadaan lahirnya maupun batinnya yang dapat berupa pandangan hidupnya, sikapnya, keyakinannya, adat-istiadatnya dan sebagainya".

a. Teknik Ekspositoris (teknik

Teknik analitik disebut juga sebagai metode langsung. Teknik analitik adalah pelukisan tokoh cerita yang dilakukan dengan memberi deskripsi, uraian, atau penjelasan secara langsung (Nurgiyantoro 2000:195). Metode analisis adalah pengarang memaparkan langsung sifat-sifat tokoh, hasrat, pikiran dan perasaannya. Kadang-kadang dengan menyisipkan kilatan atau komentar pernyataan setuju tidaknya akan sifat-sifat tokoh itu (Sudjiman 1998:23-24). 


\begin{tabular}{|c|c|c|} 
Kredo 4 (2021) \\
KREDO: Jurnal Ilmiah Bahasa dan Sastra \\
Terakreditasi Sinta 4 berdasarkan Keputusan Direktorat \\
Jenderal Penguatan Riset dan Pengembangan, \\
Kementerian Riset, Teknologi dan Pendidikan Tinggi \\
Republik Indonesia \\
Nomor: 23/E/KPT/2019. 08 Agustus 2019 \\
https://jurnal.umk.ac.id/index.php/kredo/index
\end{tabular}

b. $\quad$ Metode Dramatik (tak langsung)

Teknik dramatik adalah penampilan tokoh cerita yang mirip dengan yang ditampilkan pada drama, yaitu pengarang tidak mendeskripsikan secara eksplisit sifat dan sikap serta tingkah laku (Nurgiyantoro 2000:198). Watak tokoh dapat disimpulkan pembaca dan pikiran cakapan dan lakuan tokoh yang disajikan pengarang, bahwa juga dari penampilan fisiknya serta dari gambaran lingkungan atau tempat tokoh (Sudjiman 1998:26).

Cara tidak langsung meliputi a) dengan melukiskan keadaan kamar atau tempat tinggalnya, cara berpakainnya, cara berbicara, b) dengan melukiskan sikap tokoh dalam menanggapi suatu kejadian atau peristiwa, melalui cara ini pembaca dapat mengetahui apakah tokoh cerita tersebut seorang yang berpendidikan, acuh tak acuh, c) dengan melukiskan bagaimana tanggapan tokohtokoh lain dalam cerita bersangkutan (Suharianto 1982:32).

\section{Latar atau Setting}

Latar atau setting ialah elemen fiksi sebagai petunjuk kepada kita di mana dan kapan kejadian-kejadian dalam cerita berlangsung (Aminuddin 2000:126). Lebih lanjut, Aminuddin mengemukakan latar fiksi secara garis besar dikategorikan dalam tiga bagian yaitu latar tempat, latar waktu, dan latar sosial.

\section{Sudut Pandang}

Kosasih

(2012:70) mendefinisikan "sudut pandang atau point of view adalah posisi pengarang atau narator dalam membawakan cerita". Posisi pengarang dalam menyampaikan cerita dapat dilakukan dengan cara-cara berikut.

(1) Narator serba tahu

(2) Narator bertindak objektif

(3) Narator (ikut) aktif

(4) Narator sebagai peninjau

\section{Gaya Bahasa}

Menurut Suharianto (2005:26), bahasa dalam karya sastra mempunyai fungsi ganda, yaitu sebagai penyampai maksud, dan sebagai penyampai perasaan. Itulah sebabnya pengarang senantiasa akan memilih kata dan menyusunnya demikian rupa sehingga menghasilkan kalimat yang mampu mewadahi apa yang dipikirkan dan dirasakan tokoh ceritanya tersebut. Untuk mendukung pengungapan maksud dan perasaan tokoh cerita, pengarang banyak menggunakan kalimat-kalimat khusus yang biasa dikenal dengan pigura bahasa dengan aneka jenisnya, seperti metafora, metonimia, litotes, pleonisme, dan lain-lain. Jadi gaya bahasa adalah cara pengarang menyampaikan maksud secara tidak langsung dengan menggunakan kalimat-kalimat khusus.

\section{Amanat}

Amanat ialah pemecahan yang diberikan oleh pengarang bagi persoalan di dalam karya sastra. Amanat bisa 


\begin{tabular}{|c|c|c|} 
Kredo 4 (2021) \\
KREDO: Jurnal Ilmiah Bahasa dan Sastra \\
Terakreditasi Sinta 4 berdasarkan Keputusan Direktorat \\
Jenderal Penguatan Riset dan Pengembangan, \\
Kementerian Riset, Teknologi dan Pendidikan Tinggi \\
Republik Indonesia \\
Nomor: 23/E/KPT/2019. 08 Agustus 2019 \\
https://jurnal.umk.ac.id/index.php/kredo/index
\end{tabular}

disebut makna. Makna dibedakan menjadi makna niatan dan makna muatan. Makna niatan ialah makna yang diniatkan oleh pengarang bagi karya sastra yang ditulisnya. Makna muatan ialah makna yang termuat dalam karya sastra tersebut (Redaksi PM 2012:5).

\section{Psikologi Sastra}

Pendekatan psikologi adalah pendekatan penelaahan sastra yang menekankan pada segi-segi psikologi yang terdapat pada sebuah karya sastra. Pertama terkandung dalam ekstrinsiknya psikologi dibicarakan berkenaan dengan faktor-faktor kepengarangan dan proses kreatifitasnya. Pengarang tidak mungkin ditiadakan dalam rangka penciptaan karya sastranya (Sukada 1987:16).

Dilanjutkan menurut pendapat Aminuddin (1990:91) psikologi sastra merupakan hasil kreatifitas pengarang yang menggunakan media bahasa, dan diabdikan untuk kepentingan estetis. Karya sastra merupakan hasil ungkapan kejiwaan seorang pengarang yang berarti di dalamnya terdapat suasana rasa atau emosi. Karya sastra lahir dari pengekspresian endapan pengalaman yang telah lama ada dalam jiwanya dan telah mengalami proses pengolahan jiwa secara mendalam melalui proses imajinasi, jika endapan pengalaman yang telah cukup kuat memberikan dorongan pada batin sang pengarang untuk melakukan proses kreatif, maka dilahirkannya endapan pengalaman tersebut dalam wahana bahasa yang 621 | Jurnal Kredo

$$
\text { Vol. } 4 \text { No. } 22021
$$

dipilihnya dan diekspresikan menjadi sebuah karya sastra, sehingga pengalaman kejiwaan pengarang yang semula terendam dalam jiwa, telah beralih ke dalam karya sastra yang diciptakannya melalui ciri-ciri kejiwaan para tokoh imajiner.

\section{Pengertian Kepribadian}

Kepribadian merupakan pola khas seseorang dalam berpikir, merasakan dan berperilaku yang relatif stabil dan dapat diperkirakan (Dorland 2002:26). Kepribadian juga merupakan jumlah total kecenderungan bawaan atau herediter dengan berbagai pengaruh dari lingkungan serta pendidikan, yang membentuk kondisi kejiwaan seseorang dan mempengaruhi sikapnya terhadap kehidupan (Weller 2005).

Tipe kepribadian menurut Kartono (2005:34-45), berangkat dari sifat yaitu aktivitas, emosionalitas, dan fungsi sekunder. Berdasarkan pada ketiga sifat tersebut. Heymans (dalam Kartono 2005:34-45) membagi tipe kepribadian menjadi 8 kelompok. Tipe tipe tersebut adalah (1) nerveurs, (2) sentimental, (3) khorelikus, (4) sangunikus, (5) flegmatikus, (6) apathikus, (7) amorf, dan (8) geepasionerd.

\section{Aspek Kepribadian}

Menurut

Purwanto (1990:15), kepribadian atau personality berasal dari bahasa Latin, yaitu personare yang berarti mengeluarkan suara (to sound trough). Istilah ini, 


\begin{tabular}{|c|c|c|} 
Kredo 4 (2021) \\
KREDO: Jurnal Ilmiah Bahasa dan Sastra \\
Terakreditasi Sinta 4 berdasarkan Keputusan Direktorat \\
Jenderal Penguatan Riset dan Pengembangan, \\
Kementerian Riset, Teknologi dan Pendidikan Tinggi \\
Republik Indonesia \\
Nomor: 23/E/KPT/2019. 08 Agustus 2019 \\
https://jurnal.umk.ac.id/index.php/kredo/index
\end{tabular}

digunakan untuk menunjukkan suara dari percakapan seorang pemain sandiwara melalui topeng (masker) yang dipakainya. Purwanto (1990:156-159) menguraikan beberapa aspek kepribadian yang penting dan berhubungan dengan pendidikan dalam rangka pembentukan pribadi anak-anak, yaitu sebagai berikut:

(a) sifat-sifat kepribadian (personality traits), adalah sifat-sifat yang ada pada individu, seperti penakut, pemarah, suka bergaul, peramah, serta menyendiri; (b) intelegensi kecerdasan temasuk di dalamnya kewaspadaan, kemampuan belajar, kecakapan berpikir; (c) pernyataan diri dan cara menerima pesan-pesan (appearance and inpressien); (d) kesehatan jasmani; (e) bentuk tubuh; (f) sikapnya terhadap orang lain; (g) pengetahuan, kualitas dan kuantitas pengetahuan yang dimiliki seseorang; (h) keterampilan (skill); (i) nilai-nilai yang ada pada seseorang dipengaruhi oleh adat istiadat, etika, kepercayaan yang dianutnya; (j) penguasaan dan kuat lemahnya perasaan; (k) peranan (roles) adalah kedudukan atau posisi seseorang di dalam masyarakat di mana ia hidup; dan (l) the self, adalah anggapan dan perasaan tertentu tentang siapa, apa, dan di mana sebenarnya ia berada.

\section{Faktor-Faktor yang Mempengaruhi Kepribadian}

\begin{tabular}{rrr}
\multicolumn{2}{c}{ Menurut Purwanto (2006) } \\
terdapat $\quad$ faktor-faktor yang
\end{tabular}

mempengaruhi kepribadian antara lain: faktor biologis, faktor sosial, dan faktor kebudayaan. Dalam dunia psikologi, terdapat tipe kepribadian, yang diperkenalkan pertama kali oleh Hippocrates (460-370 SM). Hal ini dipengaruhi oleh anggapan bahwa alam semesta beserta isinya tersusun dari empat unsur dasar yaitu: kering, basah, dingin, dan panas. Dengan demikian dalam diri seseorang terdapat empat macam sifat yang didukung oleh keadaan konstitusional berupa cairancairan yang ada di dalam tubuhnya, yaitu:

(1) sifat kering terdapat dalam chole (empedu kuning);

(2) sifat basah terdapat dalam melanchole (empedu hitam);

(3) sifat dingin terdapat dalam phlegma (lendir); dan

(4) sifat panas terdapat dalam sanguis (darah).

Keempat cairan tersebut terdapat di dalam tubuh dengan proporsi tertentu. Jika proporsi cairan-cairan tersebut di dalam tubuh berada dalam keadaan normal, maka individu akan normal atau sehat, namun apabila keselarasan proporsi tersebut terganggu maka individu akan menyimpang dari keadaan normal atau sakit (Suryabrata 2007).

\section{METODE PENELITIAN}

Penelitian ini termasuk dalam kategori penelitian sastra. Kajian sastra 


\begin{tabular}{|c|c|c|} 
Kredo 4 (2021) \\
KREDO: Jurnal Ilmiah Bahasa dan Sastra \\
Terakreditasi Sinta 4 berdasarkan Keputusan Direktorat \\
Jenderal Penguatan Riset dan Pengembangan, \\
Kementerian Riset, Teknologi dan Pendidikan Tinggi \\
Republik Indonesia \\
Nomor: 23/E/KPT/2019. 08 Agustus 2019 \\
https://jurnal.umk.ac.id/index.php/kredo/index
\end{tabular}

dengan pendekatan psikologi sastra termasuk jenis penelitian kualitatif. Jenis penelitian ini merupakan penelitian kualitatif. Menurut Moleong (dalam Sangidu 2005:7) penelitian kualitatif adalah penelitian yang sifatnya alami dan menghasilkan data deskriptif berupa kata-kata tertulis atau lisan dari orangorang, perilaku, atau data-data lainnya yang dapat diamati peneliti.

Teori yang digunakan untuk meneliti novel Catatan Hati Seorang Istri adalah teori strukturalisme, hakikat novel, psikologi sastra, dan kecerdasan emosional. Strukturalisme adalah sebuah pendekatan terhadap ilmu-ilmu manusia yang berupaya untuk menganalisis bidang tertentu (misalnya mitologi) sebagai sistem yang kompleks dari bagian-bagian yang saling terkait. Itu dimulai dalam linguistik dengan karya Sausure (1857-1913), tetapi banyak cendikiawan Prancis dianggap memiliki aplikasi yang lebih luas, dan model segera diubah dan diterapkan pada bidang-bidang lain, seperti antropologi, psikologi, psikoanalisis teori dan arsitektur. Hal ini mengantarkan strukturalisme tidak hanya metode, tetapi juga sebuah gerakan intelektual yang selama ini menjadikan eksitensialisme sebagai tumpuan di tahun 1960-an Prancis.

Strukturalisme dapat dipandang sebagai salah satu pendekatan kesastraan yang menekankan pada kajian hubungan antar unsur pembangun karya sastra 623 | Jurnal Kredo

Vol. 4 No. 22021 yang bersangkutan. Analisis struktural karya sastra dalam hal ini fiksi dapat dilakukan dengan mengidentifikasi, mengkaji, dan mendeskripsikan fungsi dan hubungan antarunsur intrinsik fiksi yang bersangkutan (Nurgiyantoro 2012:60).

Sebuah karya sastra, fiksi, atau puisi, menurut kaum strukturalisme adalah sebuah totalitas yang dibangun secara koherensif oleh berbagai unsur (pembangunnya). Strukturalisme dapat dipandang sebagi salah satu pendekatan (baca: penelitian) kesastraan yang menekankan pada kajian hubungan antarunsur pembangun karya sastra yang bersangkutan. Analisis struktural karya sastra dalam hal ini fiksi dapat dilakukan dengan mengidentifikasikan, mengkaji, dan mendeskripsikan fungsi dan hubungan antar unsur intrinsik fiksi yang bersangkutan (Nurgiyantoro 2012:61).

Menurut Sudjiman (1992:23) penokohan adalah penyajian watak tokoh dan penciptaan dan cerita tokoh. Aminuddin (2013:79) menyatakan bahwa penokohan yaitu cara pengarang menampilkan tokoh atau pelaku.

Pengungkapan penokohan dapat dicapai dengan dua cara yaitu cara analitik atau secara langsung dan cara dramatik atau secara tidak langsung. Penokohan secara analitik mengungkapkan sifat-sifat, tabiat, latar belakang, pikiran, dan perasaan tokoh dikisahkan secara langsung. Penokohan 


\begin{tabular}{|c|c|c|} 
Kredo 4 (2021) \\
KREDO: Jurnal Ilmiah Bahasa dan Sastra \\
Terakreditasi Sinta 4 berdasarkan Keputusan Direktorat \\
Jenderal Penguatan Riset dan Pengembangan, \\
Kementerian Riset, Teknologi dan Pendidikan Tinggi \\
Republik Indonesia \\
Nomor: 23/E/KPT/2019. 08 Agustus 2019 \\
https://jurnal.umk.ac.id/index.php/kredo/index
\end{tabular}

secara dramatik dapat diungkapkan melalui berbagai cara antara lain dengan pengungkapan lingkungan hidup tokohtokoh, dialog, perbuatan tokoh, dan lainlain (Eneste 1991:25-27).

\section{Fananie}

(2000:87)

mengungkapkan model mengekspresikan karakter tokoh yang dipakai pengarang dapat bemacammacam, yaitu: (1) analitik artinya tokohtokoh cerita sudah dideskripsikan sendiri oleh pengarang, dengan kata lain pengaranglah yang menganalisis watak tokoh-tokohnya; dan (2) dramatik artinya pengarang tidak secara langsung mendeskripsikan karakter tokohnya. Karakter dibangun melalui kebiasaan berpikir, cara pengambilan keputusan dalam menghadapi setiap peristiwa, perjalanan karier, dan hubungan dengan tokoh-tokoh lain, termasuk komentar dari tokoh yang satu ke tokoh yang lain.

\section{HASIL DAN PEMBAHASAN}

\section{Kecerdasan Emosional Tokoh Utama Novel Catatan hati seorang Istri Karya Asma Nadia}

Wujud kecerdasan emosional tokoh utama novel Catatan Hati Seorang Istri karya Asma Nadia yang meliputi kecerdasan mengenali emosi diri, mengelola emosi, memotivasi diri sendiri, mengenali emosi orang lain, dan membina hubungan dalam cerita Kalau Saya Jatuh Cinta Lagi, Cinta Perempuan Paling Cantik, Menikah
Tanpa Memandang, Pernikahan Pertama dan Kedua, Rombongan Gadis yang Melamar Suami Saya, Kebanggan Seorang Istri, Jika Saya dan Suami bercerai, Lagi, Pertanyaan Untuk Lakilaki, Saya Tidak Ingin Cemburu ..., Saat Cinta Berpaling Darimu, Suami yang Menyebabkanku di sini, Saya Ingin Dia Memilih, Terbang Dengan Satu Sayap, Lagu Kelabu, Label Baru Seorang Istri, Sebab Aku Berhak Bahagia, Hal-hal Sederhana yang Dirindukan, $2 \times 24$ Jam, Mami, Setelah 11 Tahun, Cinta Tak Sempurna, Hari Pertama Memandangmu, dan Perempuan Istimewa di Hati Aba Agil.

Seperti Wujud Ekspresi Kecerdasan Emosional Tokoh Utama dalam bab cerita Kalau Saya Jatuh Cinta Lagi. Wujud kecerdasan emosional tokoh utama dalam cerita ini meliputi kecerdasan mengenali emosi diri, mengelola emosi, memotivasi diri sendiri, mengenali emosi orang lain, dan membina hubungan.

a. Mengenali Emosi Diri

Dalam cerita Kalau Saya Jatuh Cinta Lagi, tokoh saya dan tokoh istri mampu mengelola emosi dengan baik. Kutipan yang berkaitan dengan hal tersebut sebagai berikut:

Betapa pun, sungguh saya iri terhadap para istri yang sanggup mengikhlaskan suaminya menikah lagi. Hal yang tentu teramat sulit. Bagaimana bisa berbagi pasangan hati yang selama bertahuntahun hanya menumpukan perhatian 


\begin{tabular}{|c|c|c|} 
Kredo 4 (2021) \\
KREDO: Jurnal Ilmiah Bahasa dan Sastra \\
Terakreditasi Sinta 4 berdasarkan Keputusan Direktorat \\
Jenderal Penguatan Riset dan Pengembangan, \\
Kementerian Riset, Teknologi dan Pendidikan Tinggi \\
Republik Indonesia \\
Nomor: 23/E/KPT/2019. 08 Agustus 2019 \\
https://jurnal.umk.ac.id/index.php/kredo/index
\end{tabular}

pada kita sebagai satu-satunya istri? (Nadia 2007:6).

Proses mengenali diri yang dilakukan tokoh saya sudah sangat baik. Tokoh saya sadar betuh bahwa dalam dirinya memiliki rasa iri terhadap seorang istri yang mampu mengikhlaskan suaminya menikah lagi. Dari cerita tersebut dapat dijelaskan bahwa saya mampu mengenali perasaan yang sedang terjadi. Saya mampu lebih tenang dalam menghadapi permasalahan yang dihadapi orang lain sebagai bahan pembelajaran atas dirinya. Perasaannya yang peka membuat saya lebih tepat dalam mempertimbangkan ketika nantinya akan menentukan keputusan.

b. Mengelola Emosi

Tokoh saya dalam cerita Kalau Saya Jatuh Cinta Lagi mampu mengelola emosi dengan baik. Hal itu dapat diketahui melalui kutipan sebagai berikut.

Saya diam saja. Tidak hendak berdebat soal itu.

Hanya setelah saya tanyakan kerepotan memili dua istri, ceritanya semakin menarik. Terakhir saya tamyakan apakah dia merasa lebih bahagia setelah menikah lagi? (Nadia 2007:7)

Tokoh saya dalam cerita Kalau Saya Jatuh Cinta Lagi, mampu mengelola ketersinggungan membuatnya tetap dalam kondisi tenang sehingga mampu mendalami permasalah dengan baik. Tokoh saya pun akhirnya ikut larut dalam ceritanya yang makin mengasyikan untuk dipelajari.

c. Memotivasi Diri Sendiri

Tokoh saya di dalam cerita Kalau Saya Jatuh Cinta Lagi mampu memotivasi diri sendiri. Hal itu dapat dilihat dari kutipan sebagai berikut.

Mendengar pertanyan saya, lelaki bertubuh tinggi itu tampak termenung cukup lama sebelum menjawab,

"Yang sudah terjadi, tidak bolehlah kita sesali" (Nadia 2007:7).

Dijelaskan bahwa saya mampu memotivasi diri sendiri, dapat dilihat dari cara tokoh saya menghadapi permasalahan, saya merasa optimis sesuatu yang sudah terjadi tidak perlu disesali sehingga menumbuhkan motivasi dalam diri untuk tetap selalu bangkit apapila mengalami keterpurukan keadaan.

d. Mengenali Emosi Orang Lain

Dalam cerita Kalau Saya Jatuh

Cinta Lagi juga mampu membina hubungan dengan baik. Hal itu dapat diketahui melalui kutipan sebagai berikut.

Sementara luka hati istri pertama sudah pasti, dan itu akan abadi (Nadia 2007:5). Luka hati yang dialami seorang istri pastinya akan lama terobati seandainya dirinya dihianati oleh suami. Dari gambaran tersebut dapat dijelaskan bahwa tokoh saya mampu mengenali emosi orang lain yaitu emosi seorang istri. Saya mampu memberikan gambaran perasaan seorang istri apabila

\section{5 | Jurnal Kredo}

Vol. 4 No. 22021 


Kredo 4 (2021)
KREDO: Jurnal Ilmiah Bahasa dan Sastra
Terakreditasi Sinta 4 berdasarkan Keputusan Direktorat
Jenderal Penguatan Riset dan Pengembangan,
Kementerian Riset, Teknologi dan Pendidikan Tinggi
Republik Indonesia
Nomor: 23/E/KPT/2019. 08 Agustus 2019
https://jurnal.umk.ac.id/index.php/kredo/index

menjadi bagian dari poligami. Tokoh saya mampu mengenali emosi Pak Haris dengan memberikan tanggapan yang kiranya menjadi pertimbangan Pak haris. e. Membina Hubungan

\section{Dalam cerita Kalau Saya Jatuh}

Cinta Lagi, tokoh saya mampu membina hubungan sosial. Hal itu dapat diketahui melalui kutipan sebagai berikut.

Dialog yang berawal dari rumah makan berlanjut ke dalam mobil. Saya dan teman yang memang bekerja di penerbitan yang dikelola Pak Haris kemudian mengunjungi penerbitan beliau. Saya diperkenalkan kepada beberapa pegawai dan juga produkproduk mereka (Nadia 2007:4).

Tokoh saya mampu membina hubungan sosial dengan baik. Berawal dari obrolan biasa hingga menjadi akrab. Keduanya merasa sudah akrab dan dialog pun makin baik komunikasinya. Itu dapat dilihat dari cara saya yang mampu merespon dengan tepat perasaan Pak Haris yang sedang bercerita perihal dirinya, saya merespon dengan baik keinginan Pak haris yang kala itu terbersit keinginan untuk poligami.

Judul lain wujud ekspresi kecerdasan emosional tokoh utama yaitu bab cerita Setelah 11 Tahun. Wujud kecerdasan emosional tokoh utama dalam cerita ini meliputi kecerdasan mengenali emosi diri, mengelola emosi, memotivasi diri sendiri, mengenali emosi orang lain, dan membina hubungan. a. Mengenali Emosi Diri

Dalam cerita Setelah 11 Tahun, tokoh aku mampu mengenali emosi dengan baik. Hal itu dapat diketahui melalui kutipan sebagai berikut.

Hatiku terasa hancur berkeping-keping. Sebelas tahun perkawinan kita Cinta, dan inilah ujian terberat untukku. Kepergianmu.... (Nadia 2007:85).

Tokoh aku sadar bahwa dirinya sedang dilanda kedukaan. Duka karena telah ditinggalkan orang yang sangat disayanginya yaitu suami. Kesadaran tersebut menjadi gambaran bahwa aku mampu mengenali emosi diri. Kemampuan saya dalam mencermati perasaan ditunjukkan dari rasa sedih yang dirasakan tokoh saya mampu diketahuinya.

b. Mengelola Emosi

Dalam cerita Setelah 11 Tahun, tokoh aku mampu mengelola emosi dengan baik. Hal itu dapat diketahui melalui kutipan sebagai berikut.

Aku sendiri berusaha keras untuk tetap berpijak pada ambang kesadaran, bahwa kau telah dipanggil Sang Pencipta (Nadia 2007:175).

Dari kutipan tersebut dapat dijelaskan bahwa aku mampu mengelola emosi dengan baik. Itu dapat dilihat dari cara aku menahan keinginanya dan mencoba untuk tegar. Tokoh aku berusaha menahan emosi dalam dirinya yaitu emosi ketidakberdayaan karena kepergian sang suami tercinta. Dengan ketabahan ia memcoba untuk tetap 


\begin{tabular}{|c|c|c|} 
Kredo 4 (2021) \\
KREDO: Jurnal Ilmiah Bahasa dan Sastra \\
Terakreditasi Sinta 4 berdasarkan Keputusan Direktorat \\
Jenderal Penguatan Riset dan Pengembangan, \\
Kementerian Riset, Teknologi dan Pendidikan Tinggi \\
Republik Indonesia \\
Nomor: 23/E/KPT/2019. 08 Agustus 2019 \\
https://jurnal.umk.ac.id/index.php/kredo/index
\end{tabular}

tenang mengelola emosinya dengan memeluk kedua putri penyemangat hidupnya.

\section{c. Memotivasi Diri Sendiri}

Tokoh aku dalam cerita Setelah 11 Tahun, mampu memotivasi diri sendiri. Melalui kutipan sebagai berikut hal tersebut dapat diketahui.

Aku peluk kedua putrid kita lebih erat. Sungguh, jika tidak karena mereka, mungkin aku sudah putus asa, atau hilang kewarasan (Nadia 2007:175).

Tokoh aku mampu memotivasi diri sendiri, hal itu diketahui dari keinginan aku untuk bangkit dari keterpurukan. Aku menotivasi dirinya agar tetap kuat. Dan demi kedua putri tercintanya maka tokoh aku harus kuat.

d. Mengenali Emosi Orang Lain

Dalam cerita Setelah 11 Tahun, tokoh aku mampu mengenali emosi orang lain. Hal itu dapat diketahui melalui kutipan sebagai berikut.

$\mathrm{Aku}$ tahu untuk mereka berdua aku harus kuat dan berjuang. Tetapi beratnya Cinta, betapa beratnya harus melakukan itu semua sendiri, tanpamu (Nadia 2007:175).

Tokoh aku mempunyai rasa empatik terhadap kedua anaknya. Kedua anaknya yang sangat dicintai oleh tokoh aku. Tokoh aku merasa berat menggungnya seorang diri. Dapat dijelaskan bahwa aku mampu mengenali emosi orang lain.

e. Membina Hubungan

627 | Jurnal Kredo

Vol. 4 No. 22021
Dalam cerita Setelah 11 Tahun, tokoh aku mampu membina hubungan dengan baik. Hal itu dapat diketahui melalui kutipan sebagai berikut.

Hingga detik ini aku tidak pernah berhenti mengenangmu, Cinta. Mengenang perjalanan singkat kebahagiaan kita (Nadia 2007:175).

Dari kutipan tersebut dapat dijelaskan bahwa aku mampu membina hubungan dengan baik. Rasa cinta dan kesetiaanya terhadap suami menjadikannya hidup penuh kebahagiaan. Bahkan dengan kehidupan sederhana tanpa harta yang melimpah mereka bahagia.

Adapun contoh bab cerita lain dalam wujud ekspresi kecerdasan emosional tokoh utama dalam judul Perempuan Istimewa di Hati Aba Agil meliputi kecerdasan mengenali emosi diri, mengelola emosi, memotivasi diri sendiri, mengenali emosi orang lain, dan membina hubungan.

a. Mengenali Emosi Diri

Tokoh Aba Agil dalam cerita Perempuan Istimewa di Hati Aba Agil, mampu mengelola emosi dirinya dengan baik. Hal itu dapat diketahui melalui kutipan sebagai berikut.

Bagi Aba, hubungan biologis terlampau penting lagi. Dalam perkawinan ada hal lain yang melebihi itu (Nadia 2007:200). Aba Agil adalah tokoh yang mampu mengenali perasaanya, tokoh Aba Agil sadar bahwa hubungan biologis tidak lebih penting 


\begin{tabular}{|c|c|c|} 
Kredo 4 (2021) \\
KREDO: Jurnal Ilmiah Bahasa dan Sastra \\
Terakreditasi Sinta 4 berdasarkan Keputusan Direktorat \\
Jenderal Penguatan Riset dan Pengembangan, \\
Kementerian Riset, Teknologi dan Pendidikan Tinggi \\
Republik Indonesia \\
Nomor: 23/E/KPT/2019. 08 Agustus 2019 \\
https://jurnal.umk.ac.id/index.php/kredo/index
\end{tabular}

lagi baginya. Hal yang lebih penting daripada itu adalah tentang kesetiaan terhadap kebaikan almarhum istri yang sangat dicintainya. Aba Agil tidak bisa begitu saja melupakan kebaikan yang pernah ia dapat dan rasakan bersanya istrinya dulu.

b. Mengelola Emosi

Dalam cerita Perempuan Istimewa di Hati Aba Agil, tokoh Aba agil Aba agil tidak mampu mengelola emosinya dengan baik. Hal itu dapat diketahui melalui kutipan sebagai berikut.

Seumur-umur saya baru sekali ini melihat Aba marah demikian keras. Apalagi kami masih berada dalam suasana duka karena Ibu berpulang baru dua bulan yang lalu (Nadia 2007:194).

Aba Agil tidak kuasa menahan luapan emosinya hingga muncul luapan kemarahan. Hal itu karena permintaan untuk menikah lagi oleh anak perempuannya. Sementara itu Aba Agil masih berduka karena ditinggal oleh istri tercintanya. Istri yang sangat disayangi karena kebersihan dan kebaikan hatinya. Aba Agil belum rela sosok istri yang sangat ia cintai di hatinya tergantikan oleh orang lain. Dari keterangan tersebut dapat diketahui bahwa tokoh Aba Agil adalah orang yang tidak mampu mengelola emosinya.

c. Memotivasi Diri Sendiri

Dalam cerita Perempuan

Istimewa di Hati Aba Agil, tokoh Aba agil mampu memotivasi diri sendiri. Hal itu dapat diketahui melalui kutipan sebagai berikut.

Apa yang bisa Aba balas untuk semua kebaikan, keiklasan dan kebersihan hati Ibu Ica, menempatkan Ibu saja di hati Aba (Nadia 2007:200).

Tokoh Aba Agil mampu menata emosi, mampu memotivasi diri sendiri dan mengendalikan dorongan hati. Hal itu dapat dilihat dari rasa optimis Aba Agil menjalani hidup sendiri tanpa pendanping atau istri baru di sisinya. Rasa cinta dan sayangnya yang sangat dalam terhadap almarhum istrinya membuat hati Aba Agil kuat untuk menjalani hidup tanpa harus menikah lagi. Cukup almarhum istrinya yang berada di hati Aba agil. Itulah motivasi yang membuat aba Agil tetap kuat dan tabah.

d. Mengenali Emosi Orang Lain

Tokoh Aba agil dalam cerita Perempuan Istimewa di Hati Aba Agil, mampu mengenali emosi orang lain. Melalui kutipan sebagai berikut dapat diketahui.

Saya tahu ini gerakan yang jarang Aba lakukan, mencium tangan saya adalah ungkapan sayang yang mendalam dari Aba, meskipun saya anaknya. Aba memberikan saya senyum kelegaan (Nadia 2007:201).

Berdasarkan kutipan tersebut dapat dijelaskan bahwa tokoh Aba Agil mempunyai rasa empati terhadap anakanaknya. Tokoh Aba Agil berusaha mencurahkan rasa sayangnya melalui 


\begin{tabular}{|c|c|c|} 
Kredo 4 (2021) \\
KREDO: Jurnal Ilmiah Bahasa dan Sastra \\
Terakreditasi Sinta 4 berdasarkan Keputusan Direktorat \\
Jenderal Penguatan Riset dan Pengembangan, \\
Kementerian Riset, Teknologi dan Pendidikan Tinggi \\
Republik Indonesia \\
Nomor: 23/E/KPT/2019. 08 Agustus 2019 \\
https://jurnal.umk.ac.id/index.php/kredo/index
\end{tabular}

gerakan yang sebelumnya jarang dilakukan Aba Agil. Mencium tangan sang anak dengan penuh kasih sayang membuat hati si anak luluh dalam buaian kasing sayang yang dalam. Itulah cara Aba Agil menyampikan rasa sayangnya kepada orang lain.

e. Membina Hubungan

Dalam cerita Perempuan

Istimewa di Hati Aba Agil, tokoh Aba agil adalah tokoh yang mempunyai seni membina hubungan dengan baik. Hal itu dapat diketahui melalui kutipan sebagai berikut.

Aba meskipun telah menyusul Ibu, tetapi masih menyisakan penghormatan kami padanya. Saya bangga punya Aba Agil. Kebanggaan itu bertambah, justru ketika Aba Agil sudah tidak bersama kami lagi, lelaki yang sebetulnya dengan status sosial yang dimilikinya di Ambon, mampu beristri lagi, bahkan ketika Ibu masih hidup sekalipun... (Nadia 2007:201).

Cara Aba Agil memberi contoh anak-anaknya, agar berlaku setia menjadikannya terkenang walau sudah meninggal dunia. Aba Agil adalah suami yang sangat menyayangi istri dan keluarganya. Kesetiannya terhadap almarhum istrinya membuatnya dicintai dan disayangi pula oleh anak-anaknya. Dari keterangan tersebut dapat dijelaskan bahwa tokoh Aba Agil mampu membina hubungan dengan baik.

629 | Jurnal Kredo

Vol. 4 No. 22021
Dari seluruh kumpulan cerita karya Asma Nadia tersebut dapat penulis simpulkan bahwa wujud ekspresi kecerdasan emosional tokoh utama tokoh yang banyak mendominasi dalam cerita adalah kemampuan tokoh utama dalam memotivasi diri sendiri. Tokoh utama dalam kumpulan cerita Catatan Hati Seorang Istri karya Asma Nadia mempunyai rasa optimisme yang tinggi, tokoh utama dalam cerita ini mampu memotivasi diri sendiri dan mempunyai semangat hidup yang kuat, sehingga tidak terjatuh ke dalam keterpurukan, keputusasaan atau depresi apabila sedang dalam kesulitan. Tokoh utama selalu bangkit apabila mengalami keterpurukan.

\section{SIMPULAN}

Wujud ekspresi kecerdasan emosional tokoh utama dalam novel Catatan hati Sorang Istri merupakan kecerdasan pribadi. Kecerdasan tersebut dibagi menjadi lima bagian antara lain: mengenali emosi diri, mengelola emosi, memotivasi diri sendiri, mengenali emosi orang lain dan membina hubungan. Wujud ekspresi kecerdasan emosional tokoh utama pada novel Catatan hati Sorang Istri karya Asma Nadia titik tolaknya bertumpu pada tokoh utama pada masing-masing cerita tersebut.

Dari seluruh cerita dalam novel Catatan hati Sorang Istri, kemampuan 


Kredo 4 (2021)
KREDO: Jurnal Ilmiah Bahasa dan Sastra
Terakreditasi Sinta 4 berdasarkan Keputusan Direktorat
Jenderal Penguatan Riset dan Pengembangan,
Kementerian Riset, Teknologi dan Pendidikan Tinggi
Republik Indonesia
Nomor: 23/E/KPT/2019. 08 Agustus 2019
https://jurnal.umk.ac.id/index.php/kredo/index

memotivasi diri sendiri yang banyak mendominasi tokoh utama. Dari seluruh cerita tersebut berisi tentang kemampuan dan ketabahan tokoh utama dalam menghadapi permasalahan serta memotivasi diri sendiri. Di dalam novel tersebut kemampuan memotivasi diri sendiri sangat penting dalam kehidupan karena dapat memberikan dorongan dan semangat dalam menghadapi permasalahan.

\section{DAFTAR PUSTAKA}

Dennis H. Pulido. 2011. Saving the savior: a deconstruction of the Novel Viajero by F. Sionil Jose. 3L; Language, Linguistics and Literature, The Southeast Asian Journal of English Language Studies, 17 (1). Malaysia: UKM.

Gartner, at al. 2012. Religious commitment and mental health: Areview of the empirical literature. Intenational Journal for The Psychology of Religion, 19 (1). New York: Sage.

Grim, Brian J. 2006. International Religion Indexes: Government Regulation, Government Favoritism, and Social Regulation of Religion. International Journal of Research on Religion, 2 (1). Rockville: NCBI.

Hartono. 2006. Kepatuhan dan Kemandirian Santri Sebuah Analisis Psikologis. Jurnal Studi Islam dan Budaya, 4 (1). Purwokerto: IAIN.

Herlina. At al. Novel Rumah Tanpa Jendela Karya Asma Nadia (Kajian Sosiologi Sastra, Resepsi Pembaca, dan Nilai Pendidikan). Jurnal Pendidikan Bahasa dan Sastra, 1 (1). Surakarta: UNS.

Schmidt, Frank L. 2012. Statistical significance testing and cumulative knowledge in psychology: Implications for training of researchers. International Journal for Psichological Methods, 1 (2). Pennsylvania: The Pennsylvania State University.

Taylor, Amy E. 2002. Body and Technology: Reframing the Humanistic. United States of America. 


\begin{tabular}{|c|c|c|} 
Kredo 4 (2021) \\
KREDO: Jurnal Ilmiah Bahasa dan Sastra \\
Terakreditasi Sinta 4 berdasarkan Keputusan Direktorat \\
Jenderal Penguatan Riset dan Pengembangan, \\
Kementerian Riset, Teknologi dan Pendidikan Tinggi \\
Republik Indonesia \\
Nomor: 23/E/KPT/2019. 08 Agustus 2019 \\
https://jurnal.umk.ac.id/index.php/kredo/index
\end{tabular}

Thomas F, At al. 2006. A meta-analytic test of intergroup contact theory. International Journal of Personality and Social Psichology, 90 (5). Rockville: NCBI.

Aminuddin. 2013. Pengantar Apresiasi Karya Sastra. Bandung: Sinar Baru Algensindo

Casmini. 2007. Emotional Parenting. Yogyakarta: Pilar Merdeka.

Eneste, Pamusuk. 1991. Novel dan Film. Ende: Nusa Indah.

Fananie, Zainuddin. 2002. Telaah sastra. Surakarta: Muhammadiyah Universiti Press.

Goleman, Daniel. 1997. Emotional Intelligence (Kecerdasan Emosional). Jakarta: Gramedia Pustaka Utama.

Nadia, Asma. 2011. New Catatan Hati Seorang Istri. Depok: Asma Nadia Publising House.

Nurgiyantoro, Burhan. 2012. Teori Pengkajian Fiksi. Yogyakarta: Gajah Mada University Press.

Sangidu. 2005. Metode Penelitian Sastra, Metode dan Kiat. Yogyakarta: UGM

Sudjiman, Panuti. 1992. Memahami Cerita Rekaan. Jakarta: Pustaka Jaya.

Sudjiman, Panuti. 1996. Kamus Istilah Sastra. Jakarta: Pustaka Jaya.

Suharianto, S. 2005. Dasar-Dasar Teori Sastra. Semarang: Rumah Indonesia.

Kartika, Diana Ayu. 2008. Konflik Batin Tokoh Utama Novel Nayla Karya Djenar Maesa Ayu: Tinjauan Psikologi Sastra”. Skripsi. Surakarta: UMS.

Nugraheni, Astin. 2006. Konflik Batin Tokoh Zaza dalam Cerpen Azalea Jingga Karya Naning Pranoto: Tinjauan Psikologi Sastra. Tesis: UMS.

Simma, Watcharapipat. 2009. An Analysis of Defense Mechanisms Used by The Main Characters in Mark Twain's The Adventures of Huckleberry Finn and The Prince and The Pauper. Bangkok: Graduate School, Srinakharinwir of University.

631 | Jurnal Kredo

Vol. 4 No. 22021 